\title{
駿河海岸の侵食に伴う藤守・杤山川河口部の地形変化と新河口処理方式の提案 \\ Topographic changes of Fujimori and Tochiyama River mouths caused \\ by beach erosion and new river mouth improvement
}

\author{
宇多高明 $*$ ・ 小菅 晋 $* *$ ·松田 勝 $* * *$ \\ Takaaki Uda, Susumu Kosuge and Masaru Mazuda
}

\begin{abstract}
Topographic changes associated with beach erosion around the Fujimori and Tochiyama River mouths located on the Suruga coast were investigated by using aerial photographs and beach survey data. Shoreline recession around these river mouths is very severe and high berm closed the river channel to cause water level rise in the upstream of the river. A new method to prevent forming high berm is proposed by installing wave dissipating breakwater in front of the river mouth.

Keywords:River mouth improvement,Beach erosion.
\end{abstract}

\section{1.まえがき}

駿河海岸や富士海岸などのように急深な海岸に流入する小河川では、しばしば河口が閉塞され，内水排 除に問題が生ずる.これらの急深な海岸では海浜構成材料は一般に䃯や粗砂からなり，また汀線付近の勾 配が急なため河口砂州の高さが高くなり，これが原因して内水排除が困難となるのである。こうした河口 閉塞に対して種々の対策がとられてきているが，大河川と異なり平常時の流量規模が小さい小河川では有 効な閉塞防止手法があまりないのが現状である.ほた，これらの海岸では沿岸漂砂の移動が活発であって， 河口に導流堤を伸ばすとその下手海岸での侵食が助長されるために，大規模な導流堤の建設は不可能であ る.したがって沿岸漂砂を自由に通過させつつ, 河口を維持することが求められる.しかしながらこのよ うな動的平衡状態を各種構造物により造り出し，それを保つことはかなり難しい．本研究ではこの種の問 題について具体例を通じて検討しようとするものであり, 駿河海岸に流入する藤守川と杤山川河口を実例 として, 海岸侵食に伴う河口状況の変化について考察しつつ, 新たな河口処理工法の提案を行う.

\section{2. 駿河海岸の概要}

駿河海岸は駿河湾西岸にあり, 延長 $18 \mathrm{~km}$ の海岸線を有する砂砅海岸である (図-1 参照). 海岸中央部に は大井川が流入し，ここからの流出土砂が駿河海岸の主な漂砂源となってきた．武内ほか（1984）に述べ られているように, 河口以北の海岸においては河口からの流出土砂が北向きの沿岸漂砂により運ばれてい たが，現在は大井川港の防波堤と吉永放水路の建設により北向きの沿岸漂砂は阻止されている.また，No.12 付近の和田鼻では海岸線近くまで海底谷が迫ってお り，この谷を経由する沖への土砂流出も報告されてい る（宇多ほか, 1987)。一方, 大井川港の北側の海岸 侵食を軽減するために, 1983 年以降, No.36 付近では 大井川港の防波堤の南側へ堆積した土砂によるサンド バイパスが行われてきており，年間約 6 万 $\mathrm{m}^{3}$ U土砂 が投入されている（滝澤ほか，1986）。図-1には，以 後の解析の便を考えて測線番号と本研究で詳細調查を 行う藤守川および杤山川の河口位置を示す.

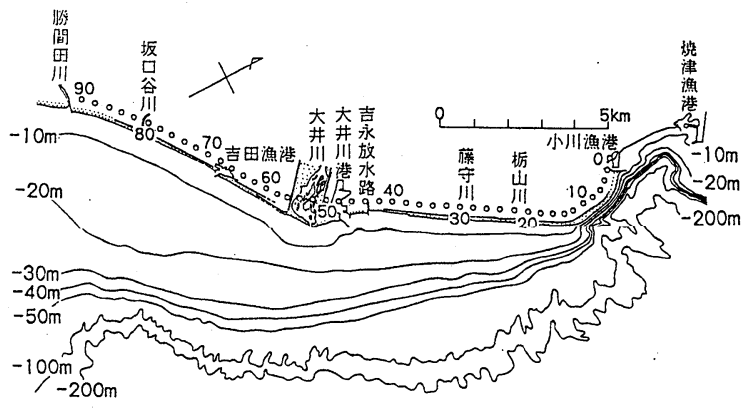

\section{3. 駘河海岸の汀線変化}

図-1 駿河海岸および藤守川, 杤山川の位置図

図-2 には駿河海岸の測線 No.4〜 No.42 の範囲における 1974. 年から 1993 年までの汀線変化を示す. 測線 間隔は $200 \mathrm{~m}$ なので全体で約 $8 \mathrm{~km}$ 区間の汀線変化である．対象区間のうち，藤守川河口は No.29に，栃山川 河口はNo.21 に位置している.また, No.42の南（右）側 $0.4 \mathrm{~km}$ には吉永放水路が, また No.4の北 (左) 側 $0.4 \mathrm{~km}$ には小川漁港の防波堤がある. 図-2 により近年の汀線変化を調べると, 藤守川河口の南側直近の No.30を 境としてその南側では汀線はやや前進傾向を示すのに対し, No.30 以北の汀線は著しい後退傾向を示す. 河

\footnotetext{
*正会員 工博 建設省土木研究所河川部長（率305 茨城県つくば市旭 1)

**正会員 工博 東海大学海洋学部海洋土木工学科教授

*** （株）三水コンサルタント
} 
口の北側での汀線後退は最初河口周辺で著しく, 汀綠の 後退量が約 $50 \mathrm{~m}$ に達するとその場所での汀線の後退は止 まり，時間経過とともに侵食域が北側へと広がった。こ の理由は, 北向きの沿岸漂砂の供給不足により侵食が生 じるものの, 汀線が大きく後退すると消波堤が設置され, それ以上の汀線の後退が防がれたためである。これによ りその地点の汀線の後退は防がれたが，侵食域は北側へ と広がった.No.21 にある杤山川の河口では 1974 年には 約 $70 \mathrm{~m}$ もあった前浜が著しく狭くなった. 汀線の後退は No.15 以南で著しく, 砂嘴状に汀線が突出し, 前浜幅が広 いNo.12 では近年も汀線が前進傾向にある．以上のよう に, 駿河海岸の藤守川および杤山川河口周辺部では No.30 以南では汀線が前進傾向, No.30〜 No.15 では後退傾向と なっている. No.38 の南 $1.2 \mathrm{~km}$ には吉永放水路があって沿 岸漂砂が阻止されていることから, No.30〜 No.38です汀 線前進はそのほとんどが養浜工によると考えられる.

一方, No.15 No.30 では No.30より養浜土砂の一部が 流入するのに対し No.15 から北向きに沿岸漂砂が流出す るために侵食が生じている。

次に, 藤守川では河口の北側に隣接する. No.28 と No.27 を, 杤山川では同じくNo.21 と No.20を選び, これらの測 線位置における汀線変化をまとめると図-3 となる。まず,

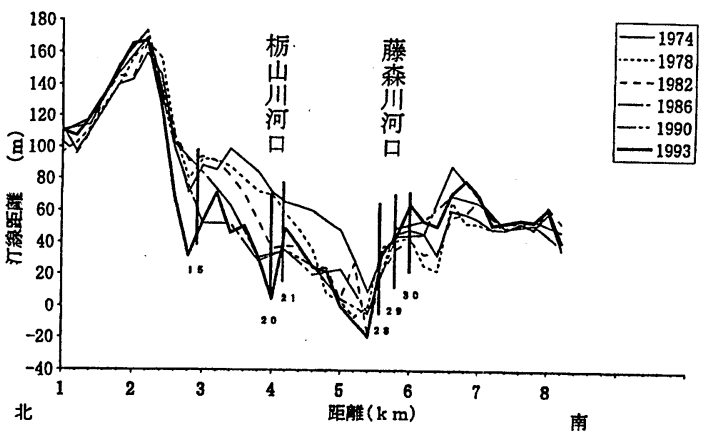

図-2 駿河海岸の汀線変化

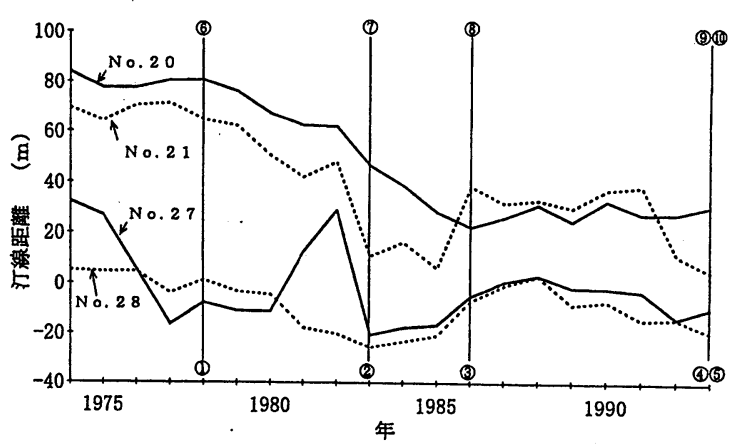

図-3 藤守川・杤山川河口部の汀線の経年変化 No.28, No.27 では 1974 年当時すでに汀線が後退してしま つており，汀線幅は 5〜30m と狭かった。 その後，1984 年までは全体的に汀線が後退傾向を示したが，藤 守川河口より南 $3.2 \mathrm{~km}$ 地点においてサドバ价スによる土砂投入の始まった 1983 年以降，1987 年頃までは汀 線は再び前進した．しかし最近では汀線は再び後退傾向に転じた。これに対し，No.21，No.20では，海岸 侵食による汀線後退が遅れて始まった。1979 年頃までは杤山川の汀線は緩やかな後退を示すに止まり，前 浜幅は少なくとも約 $70 \mathrm{~m}$ はあった.しかし 1979 年以降汀線の後退が激しくなり，1986 年までに汀線は約 $40 \mathrm{~m}$ も後退した．その後 1986 年以降は変動を有しつつ汀線幅は約 $30 \mathrm{~m}$ の一定值を保ってきたが，最近ではNo.21 で再び汀線の後退が目立っている.なお図-3には後述する写真-1～10の撮影時期を番号(1) (10)で示す.

\section{4. 空中写真の比較}

(1)藤守川河口部の状況

以下では河口部の空中写真を示すが，写真撮影時斯と汀線変化との関係は前出の図-3にまとめて示して ある. まず, 1978 年 12 月 21 日撮影の藤守川河口部ひ状況を写真-1に示す. 藤守川河口部付近はこの段階 で既に著しい汀線の後退は生じてしまっており，写真-1に示すように河口の両岸には消波堤が設置されて 汀線の固定が図られていた。また河口前面には右岸側より斜めに導流堤が伸びており，流下した河川水は この導流堤の内側に沿う狭い水路を経由して沖合へ流出している.河口の北側には 5 基の消波堤が設置さ れているが, その北端（写 真最上部） では汀線が 不連続とな つて後退し ている.こ のことは沿 岸漂砂が北 向きに流れ ていたこと を示す。し かしこの段

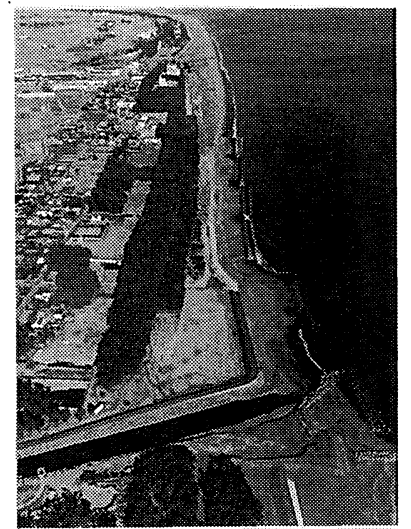

写真-1 藤守川河口部の状況 (1978年 12 月 21 日撮影)

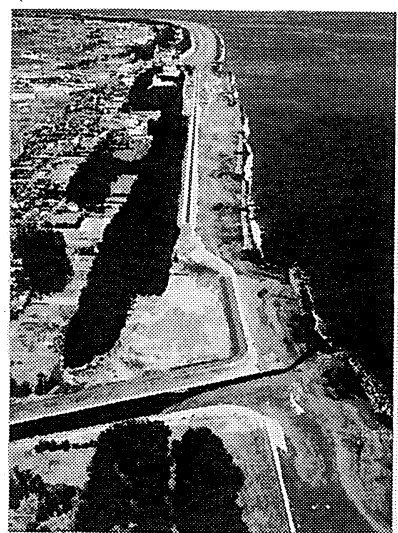

写真-2 藤守川河口部の状況

（1983 年3月 19 日撮影）

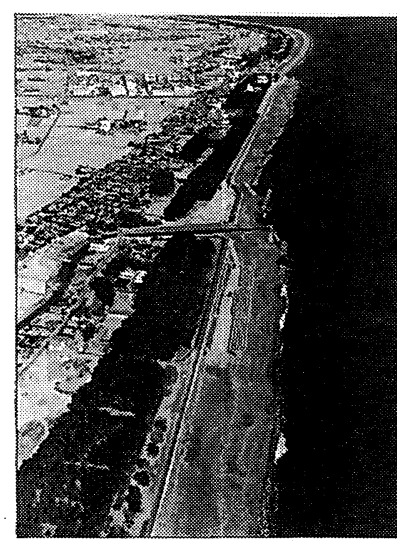

写真-3 藤守川河口部の状況 (1986 年 2 月撮影) 
階では写真上方に見られる栃山川河口部付近までは汀線の後退は波及していない.

写真-2 は 1983 年 3 月 19 日の河口状況である．河口部での施設配置は 1978 年当時と同一であるが，汀線 付近の堆積土砂と同一色調の土砂が河口の右岸側に広がっていることから, 高波浪の作用により右岸導流 堤をのり越えて河道内へ土砂がうち込まれたことが分かる。このため 1978 年当時右岸導流堤に沿う狭い水 路より海へ流出していた河川水は, 左岸沿いに流下することになった。一方, 海岸部では海岸堤防と消波 堤の設置区域が杤山川河口付近にまで及び，杤山川河口以南の汀線の維持が図られたと同時に，栃山川以 北の汀線が河口を中心として大きく後退した. 1986 年 2 月の河口部および海岸の状況を写真-3に示す.藤 守川の河口部では写真-2 と比較して大きな変化は見られず, 狭い水路が左岸側に沿って開き, 消波堤背後 の波の作用の弱い場所より海へ流入している. 河口周辺の海岸部でも大きな変化は見られないが, 写真上 方の杤山川河口部での汀線の不連続が際立っている.

1993 年 1 月, 2 月の河口部の状況をそれぞれ写真-4, 5 に 示す. 写真-4によれば藤守川の河口では左岸側より河口砂 州が発達し, 河川流は一度左岸導流堤に沿って流れたあと, 河口前面にある消波堤背後の砂州を横切って沖合へと流出 している. 河口前面の消波堤はちょうど離岸堤と同様な消 波効果を発揮し, その背後の砂州高は低下するため, そこ から河川流が流入し, 河川流はこの消波堤背後でほぼ沿岸 方向へと流れている.この消波堤は河川の全幅いっぱいに 伸びているから，洪水時には水位のせき上げ要因となる. しかしながら通常時の河川での排水を考えると, 河口前面 を塞ぎ，波高を低下させることが必要となったのである。 写真-5 に示す 1993 年 2 月の海岸状況を見ると, 藤守川河口. の南側（写真下部）では海岸線は消波堤と短突堤とによっ て守られ，またこの地区の上手側の No.36 付近で年間約 6 万 $\mathrm{m}^{3}$ の養浜工が行われているため, その土砂が消波堤の開 口部より岸側へ大きくうち上げられていることがわかる. 藤守川河口では白いブロックの状況より, 河川の流下方向 と直角方向に段違いに 2 基の消波堤が設置されている。こ のような段違い消波堤は, ちょうど先端の開口部を沿岸漂

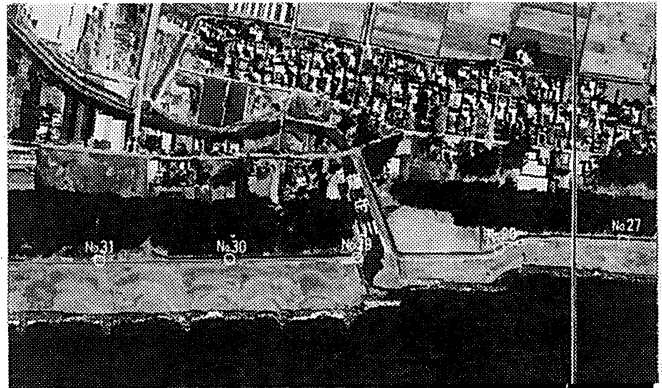

写真-4 藤守川河口部の状況（1993 年 1 月撮影）

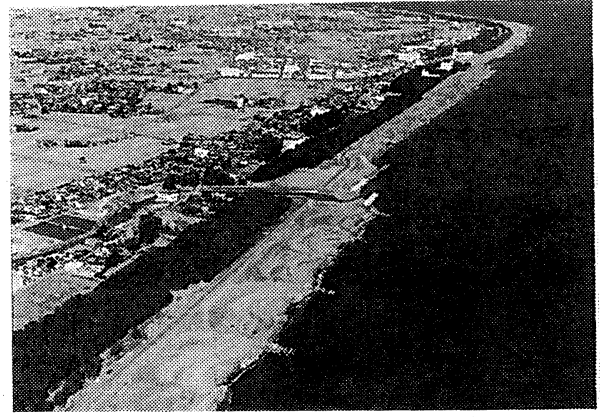

写真-5 藤守川河口部の状況（1993 年 2 月撮影） 砂の下手方向へ向けた暗渠と同等な効果を有している.このことから見ても，藤守川のような小河川では 河口前面をそのまま開けるのではなく，波の作用を防ぐために消波堤や離岸堤により河口を塞ぐことが必 要とされる.

(2)杤山川河口部の状況

1978 年 12 月 21 日に撮影した杤山川河口より和田鼻を望む状況を写真-6に示す.この時点では河口の右 岸側にある透過性の導流堤を除けば海岸線には消波堤などの構造物はなく, 汀線は河口部も含め連続的に 伸びていた．河口には右岸（南）側より砂州が伸びているため幅が約 $1 / 4$ ほどに縮流されていたが，開口部 の沖の砕波帯における砕波状況が周辺部と何ら変わらないことから, 河口部は非常に浅く, 北上する沿岸 漂砂が自由に通過するこ とにより動的意味で河口 が維持されていたと考え られる。また汀線に沿っ て約 $30 \mathrm{~m}$ 幅で伸びる波の うちあげ帯を示す帯状の 区域も導流堤を挟んで南 北で連続的に伸びている. このこともまた，この当 時沿岸漂砂が連続的に通 過する条件にあったこと を示している.

写真-7には, 同じ地区 の 1983 年 3 月 19 日の状

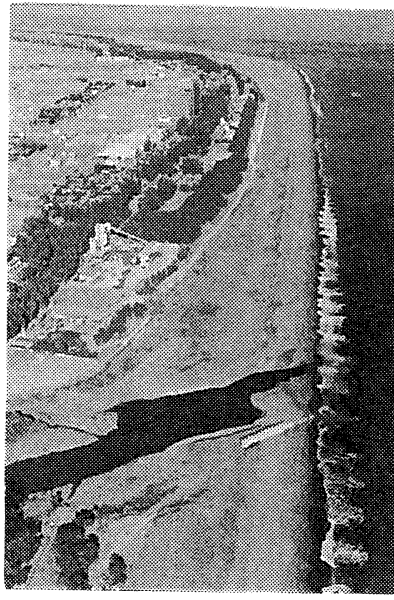

写真-6 栃山川河口部の状況 (1978 年 12 月 21 日撮影)

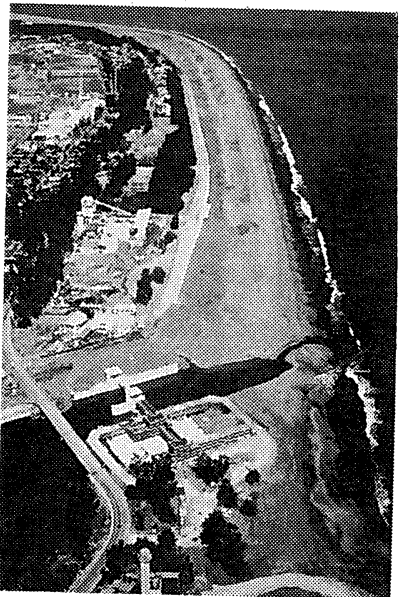

写真-7 杤山川河口部の状況 (1983 年 3 月 19 日撮影)

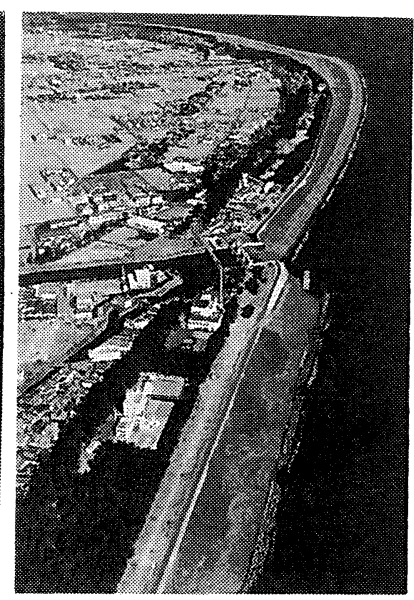

写真-8 栃山川河口部の状況

(1986 年 2 月撮影) 
況を示す. 写真撮影方向がやや東へ傾いたものの, ほぼ同様な空中写真である.この当時, 河口には津波 水門の工事が進められつつあった。 また河口右岸の導流堤の位置と汀線形を写真-6，7 で比較すると，1978 年〜 1983 年の間で汀線がかなり後退したことが分が. しかし, 汀線が後退しても右岸側から河口砂州が 伸び, 左岸側に幅の狭い水路が維持されている点では写真-6 と同様である.

図-3によると, 杤山川河口部の汀線は 1979 年以降著しい後退傾向を示し, 1986 年に至ってほぼ安定状態 に達した。この時点（1986 年 2 月）．における河口部の状況を写真-8 に示す. 1983 年には河.口の右岸（南） 側より北側へと直線状に伸びていた汀線には，河口位置で大きな不連続が生じた．写真に示すように河口 の南側の海岸にはほぼ連続的に消波堤が並べられて汀線が固定されたのに対し, 河口から北側には沿岸漂 砂を阻止する構造物が何もないので, 河口地点で漂砂の著しい不連続が生じ, このため河口の汀線が大き く後退したのである. 図-3 において, 河口の左岸側隣接部の No.20 の汀線変化によれば, 写真-6（1978 年 撮影）より写真-8（1986 年撮影）間の 8 年間で汀線は約 $40 \mathrm{~m}$ 後退している.したがって写真-8 は, 約 $40 \mathrm{~m}$ の汀線後退後の状況を示している.

写真-9，10 にはそれぞれ 1993 年 1 月と 2 月の空中写真を示 す。写真-9 によると，杤山川の両側の海岸線は既に消波堤が 設置され，汀線が固定されている．河口内の水門の前面には 標高約 $2 \mathrm{~m}$ の河口砂州が大きく発達し, 河口のほとんど全部を 塞いでいる. 前面の砂州は幅が $45 \mathrm{~m}$ と広く，また前浜材料は 砂であること，そして高さが約 $2 \mathrm{~m}$ と高いために，杤山川の流 量規模を考えると洪水時に越流により砂州がフラッシュされ ることは非常に困難であろう。したがって水門は 3 基あるが, 事実上それらの 2 基は機能を言失していると言ってよい，残 る 1 門の前面においても水路幅は非常に狭い。この海岸での

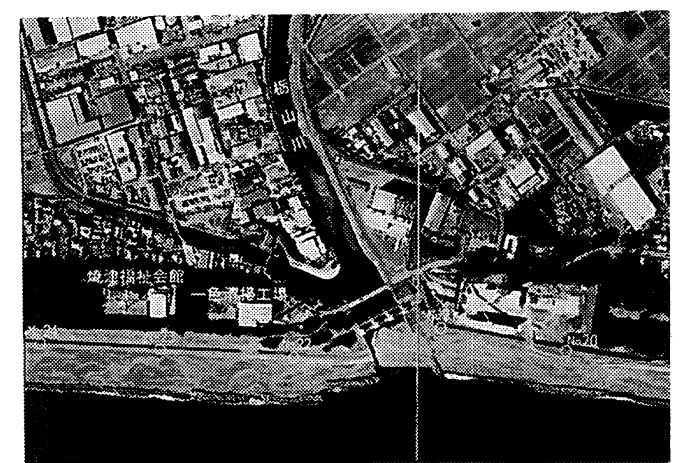

写真-9 栃山川河口部の状況（1993 年 1 月撮影） 沿岸漂砂の卓越方向は南から北, すなわち写真では左から右方向である. このことは同時に波がやや左側から入射することを意味する。この波の入 射条件を考慮したとき，河川流は波が最も遮蔽されるよう右岸導流堤に沿 って流れ，その後消波堤の陰より海へ流入していることになる．このこと は通常時の流量規模の小さな河川では, 波が遮蔽されて作用波高が低く, その結果砂州高が低い場所を造らない限り排水不良が起こることを意味し ている. 海岸状況を斜めに撮影した写真-10 と写真-8 とを比較すると, 河 口の北側地区にも 7 基の消波堤が設置され，これらの消波堤が北向きの漂 砂移動を阻止するために, 河口部では再び汀線が前進し, 消波堤群の最も 北側では汀線がフック状に湾入している。このように海岸では現在も沿岸 漂砂に上る海浜恋形が続いており，消波堤群の北端が侵食にさらされてい る. 一方, 写真-10より河口部の状況を調べると, 河口前面において大量 の堆砂が生じていることと, 河口砂州と水門の間にごく狭い水路があるこ とが分かる.以上のように杤山川河口部は 1978 年当時広い前浜があったが, その汀線は近年急速に後退し, 河口水門のごく前面まで波の作用により土 砂堆積が生じるようになったことがわかる，そして河口部の汀線のさらな

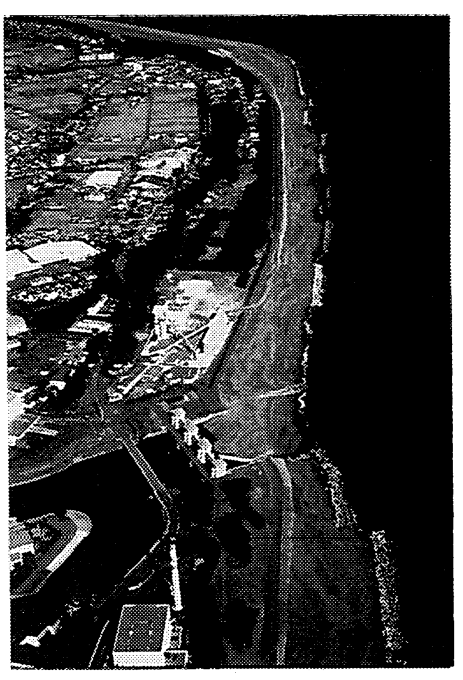

写真-10 板山川河口部の状況 (1993 年 2 月撮影) る後退が生ずると, 水門前面に土砂が直接堆積し, 水門の開閉も困難になると考えられる。したがって現 況汀線のこれ以上の後退を防ぎつつ, 水路を維持することが必要である.

\section{5. 海浜縦断面形の比較}

図-2 の汀線変化図をもとに，いくつかの断面を選び海浜 縦断面形の比較を試みる. まず, 図-4 は藤守川河口の西 $200 \mathrm{~m}$ に位置する No.30 の海浜縦断面形である. この断面は, 写 真-4 に示したように藤守川河口より南側に 3 番目の消波堤 のほぼ中央を横切っている. 図示するように、この消波堤 はほぼ T.P.- $1 \mathrm{~m} \sim 1.0 \mathrm{~m}$ に設置されている.この断面で浮 1985 年以降大きな汀線変化は見られなかったが、消波堤の設置 前後の比較においても汀線およびその沖合部では著しい侵 食または堆積傾向は見られない，次に、図-5には河口より

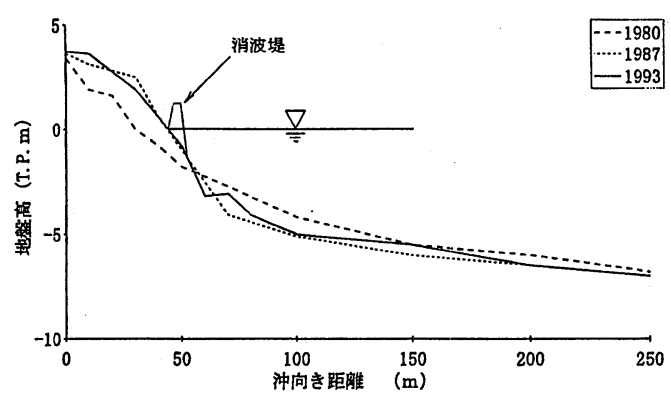

図-4 测線 No.30 の海浜縦断面形の経年変化 
東に $200 \mathrm{~m}$ 離れた No.28 の断面形を示す.ここは 1979 年以 降かなり激しく汀線が後退した測線である.図-4に示した No.30 では陸上部〜約 $-4 \mathrm{~m}$ 間が鉛直上方に凸な, 堆積断面 の特徵を示したが, No.28 では経年的に侵食が進み, 汀線 付近が全体に上に凹な断面形となった.

宇多・野口（1990）は；沿岸漂砂の場所的不均衡が原因 して海浜縦断面形の変化が起こる場合, 海浜縦断面形の経 時的変化は場所的変化とほぼ同等となることを示した。こ の概念を利用すれば、ある時期の媣浅データより海浜縦断 面形の経時変化特性の推定が可能である.すなわち地形変 化に関する空間と時間の変換が可能となる。これが利用で きるのは, 沿岸漂砂による地形変化が生じた場合, 地形変 化の限界水深付近より沖合の等深線形状が沿岸方向にほぼ 一様な場合であって，このとき沿岸方向に配置された断面 形の重ね合わせ比較が可能となる。駿河海岸では図-4, 5 より地形変化の限界水深は-6〜-7mにあると考えられるが， 図-1に示したように限界水深より沖の水深 $10 \mathrm{~m}$ の等深線は 沿岸方向にほぼ一様である。このことから藤守川河口を挟 む 4 断面を選んで断面形の重㸚合わせを試みた。図-4, 5 の断面を基準点をそのままにして重ね合わせたところ，結 果的に波による地形変化が見られなくなる水深約 $7 \mathrm{~m}$, 沖 向き距離 $250 \sim 400 \mathrm{~m}$ 間の断面が一致を示した。結果が図-6

（測線 No.27〜 No.30）である.これによると，河口の右 岸側に位置し，消波堤により守られると同時にNo.36 付近 で行われている養浜工の砂礫が消波工と短突堤による漂砂 阻止効果により堆積している No.29, No.30では汀線付近が 著しく凸状となり，また沖合の勾配も緩いのに対し，河口 の左岸側に位置する No.27，28 では汀線付近が凹状でかつ その沖合も急深となっていることがわかる. そして No.29, No.30はあたかも経時的に土砂が堆積したかのように，ま た No.27, No.28 は経時的に侵食されたかのような断面変化 状況を示している. 駿河海岸では沿岸漂砂による地形変化 が卓越していることを考慮すると、このことはこれらの縦 断面形に著しい違いの見られる-6m 以浅の区域で沿岸漂砂 移動が活発であることを意味している。

図-7 は杤山川河口右岸側の No.22 の断面変化である.こ の断面では 1980 年〜 1987 年の閒, 汀線が約 $8 \mathrm{~m}$ 後退する とともに，沖合部で侵食が進んだ。その後汀線の後退防止 を目的として消波堤が設置されたため，地形変化は小さく なり, 1993 年と 1987 年の断面形には大きな差はない. これに対し河口左岸に位置する No.20では, 図-8に 示すように 1980 年〜 1987 年の間に $44 \mathrm{~m}$ もの汀線後退が生じ, 海岸堤防の前面が深くなった.さらに, 図-8 に示す縦断面形の経時変化が，図-6に示した断面形の重ね合わせ図における各測線の場所的な変化と非常 によく似ていることは、再び汀線付近での漂砂が非常に活発なことを示す.

\section{6. 海浜土砂量の変化と沿岸漂砂量}

各区域の土砂量の変化を調べるために, 堆積・侵食変化の明瞭な No.15 No.28 区間と No.30〜 No.38 区 間でそれぞれ 1974 年以降の経年的な前浜面積の変化量を求め, さらに武内ほか（1984）の求めた駿河海岸 における漂砂の移動高 $8 \mathrm{~m}$ を乗じて総土砂量に換算し，図-9に示した。これによるとNo.30〜 No.38 間では 1983 年〜 1987 年の間約 4 万 $\mathrm{m}^{3} / \mathrm{yr}$ の割合で土砂量が増加したが，その後は海浜面積の増加は見られない. このことは近年では投入土砂はNo.30より北側へと流出していることを示す. 村田ほか (1991) は，1985 年と 1990 年の深浅データより，この期間に藤守川河口を通過した漂砂量を 3.3 万 $\mathrm{m}^{3} / \mathrm{yr}$ と推定したが，上述 
の漂砂量はこの量と近い結果である. 一方, No.15〜 No.28 では 1975 年〜 1985 年では約 7 万 $\mathrm{m}^{3} / \mathrm{yr}$ の割合で土砂が流出しでいた が，1985 年〜 1993 年では漂砂量は約 2 万 $\mathrm{m}^{3} / \mathrm{yr}$ と減少傾向にあ る. 村田ほか (1991)は、1985 年〜 1990 年で No.12を通過する漂 砂量を 5.4 万 $\mathrm{m}^{3} / \mathrm{yr}$ と推定しているが, 図-9 によると 1990 年〜 1993 年の変化量がわずかであるからほぼ対応する上言える.

\section{7. 考察}

上述のように、藤守川および杤山川河口では数万 $\mathrm{m}^{3} / \mathrm{yr}$ のオー ダーの北向きの沿岸漂砂の場所的不均衡に起因して侵食が進ん できた。これらのうち沿岸漂砂の上手側に位置し，したがって

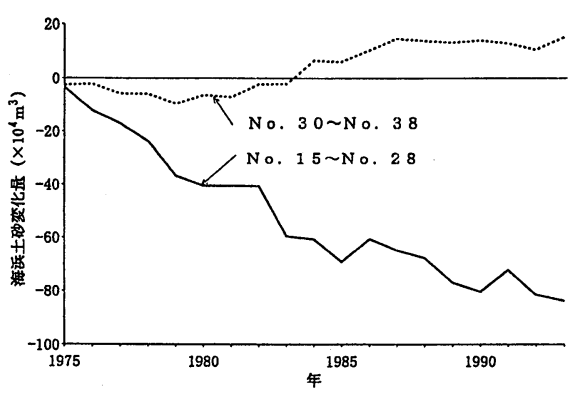

図-9 測線 No.15 No.28 と No.30 No.38 の海浜土砂量の経年変化 早くから侵食にさらされてきた藤守川河口では, 河川水は右岸導流堤に沿って流れたあと, 汀線よりわず か沖合に設置された消波堤の背後を通過して海へ流れ込んでいる。そしてこの状態は河口部で沿岸漂砂が 通過していても安定的に推移してきている，従来，藤守川のような小河川では河口処理工として図-10aに 示すような導流堤が用いられることが多かったが，このタイプの処理工では急勾配海岸特有の汀線付近で 活発な沿岸漂砂を大きく阻止するので、ただちに下手側が侵食されると同時に、導流堤の上手側に堆積し たあと過利な土砂は導流堤の先端を回り込んで河道内へ侵入することになる.さらに導流堤間への侵入波 の波高低減効果は小さいから、高い砂州が形成される。これに比べると，図-10b または写真-5 のように、 河口前面において漂砂の下手側の消波堤を後退させて設置し、河 口内への侵入波の波高低減を図ると同時に、上手側からの沿岸漂 砂は消波堤を越えて下手方向へ流せば、周辺への影響を小さくで き、また河道内に土砂が堆積したとしても消波堤の消波効果によ り砂州高は図-10a の場合と比較して低くなる。こりことから、こ の方式は導流堤方式より効果的と言える. 一方、この方式で洪水 疎通能力の低下が問題となるのであれば、消波堤間の間隔を調整 すればよいと考えられる.この案は、侵食の結果琴在のようにな った藤守川の河口が閉塞から免れている事実をもとに、その合理 性を現地データより学んだものにほかならない. 河口に津波水門 がある杤山川河口では、河口砂州の後退が一層進み, 水門の前面 に大量の砂磁が堆積すれば津波対策には有効であっても, 洪水時 にゲートの巻き上げが困難になる．このことから、杤山川では今 後の河口処理として図-10bの方式が有効と考える.

\section{8.あとがき}

(a) 慗流堤方式
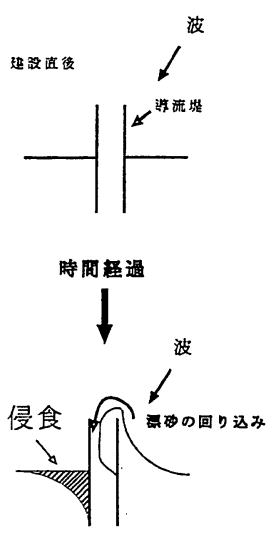

図-10 各種河口処理方式

本研究では, 藤守川河口における導流堤 +2 列の消波堤（離岸堤）が河口閉塞防止工法として有効なこ とを実態論的に明らかにした．原理的に考えると，作用波高が低く，したがって砂州高が低い所を造れば そこから平常時に河川水が排水できるということになり，この考え方は少なくとも波浪減衰を考えない平 行導流堤に比べて合理的であることはまちがいない．またこれはその吐口部を沿岸漂砂の下手方向に開け た暗渠と共通の原理を有することからもその有効性は高いと考える.今後はこの方式について現地河川の 河口で実証的研究を進めたいと考えている.

\section{参考文献}

宇多高明・堤 博志・小俣 篤・酒井佳治 (1987)：海底谷への土砂移動の現地観測, 第 34 回海岸工学講演 会論文集, pp.307-311.

宇多高明・野口賢二 (1990)：富山県東部宮崎・境海岸における海浜変形の実態, 地形, Vol.11,No.4,pp.337-347. 武内達夫・宇多高明・中島秀樹・青山春男（1984）：駿河海岸における海浜地形変化の解析, 第 31 回海岸 工学講演会論文集, pp.360-364.

滝澤俊二・宇多高明・堤 博志・中山 修（1986）：駿河海岸におけるサンドバイパスの現地実験, 第 33 回海岸工学講演会論文集, pp.302-306.

村田 守 - 宇多高明 - 片岡賢一・大石英雄 - 山本幸次 (1991）：駿河海岸の海浜変形と土砂収支, 海岸工学 論文集, 第 38 巻, pp.281-285. 